\title{
Młody Dawid. \\ Postać pretendenta do tronu ukazana na tle konfliktu ze starym królem w krymskokaraimskim tłumaczeniu maskilskiego dramatu
}

\author{
Dorota Smętek \\ Uniwersytet im. Adama Mickiewicza w Poznaniu, Wydział Neofilologii \\ Zakład Turkologii, Mongolistyki i Koreanistyki
}

Young David. The character of the pretender to the throne in the context of the conflict between himself and the old king in a Karaim translation of a maskilic drama

Summary: This article discusses the biblical figure of David as depicted in a Crimean Karaim translation of a maskilic drama called Melukhat Sha'ul'Saul's Kingdom'. The character of the future king is presented in the context of his relationship with the other main characters of the play, namely king Saul, his son Jonathan and daughter Michal. Moreover, the article demonstrates differences in the manner in which David's early life is depicted and interpreted that distinguishes it from the drama described in The First Book of Samuel.

Keywords: king David, king Saul, maskilic drama, Crimean Karaim literature, Joseph Ha-Efrati Tropplowitz

Celem niniejszego artykułu jest przedstawienie charakteru młodego Dawida w czasach zanim został następnym królem Izraela oraz jego relacji z biblijnymi postaciami ukazanymi w Pierwszej Księdze Samuela, między innymi z ówczesnym władcą - Saulem. Swoje badania opieram na rękopisie (nr kat. 
VI-3/22, zbiory kongregacji karaimskiej w Eupatorii) krymskokaraimskiego tłumaczenia maskilskiego dramatu Meluḳat Ša'ul 'Królestwo Saula' ${ }^{1}$. Autorem dzieła jest Józef Ha-Efrati Tropplowicz, który żył i tworzył na przełomie osiemnastego i dziewiętnastego wieku. Tropplowicz był poetą ${ }^{2}$ i dramatopisarzem, pisał zgodnie z duchem ruchu haskali (Skolnik 2007: 195). Przekład dramatu na język turkijski został przygotowany przez Abrahama ben Jaszara Łuckiego na Półwyspie Krymskim w pierwszej połowie dziewiętnastego wieku³.

Niewiele jest krymskokaraimskich sztuk teatralnych, które zachowały się do dnia dzisiejszego ${ }^{4}$. Każda z nich jest cennym źródłem informacji o duchowej i intelektualnej spuściźnie Karaimów krymskich. Sztuka, na której opieram rozważania zawarte w tym artykule, nie jest co prawda oryginalnym dziełem karaimskim, została jednak wiernie i skrupulatnie przetłumaczona na używaną przez Karaimów literacką odmianę języka krymskotureckiego. Ponadto w dziewiętnastym wieku była wielokrotnie kopiowana do krymskokaraimskich rękopiśmiennych książek ${ }^{5}$, które były odczytywane w rodzinnym gronie. Dlatego poznanie jej umożliwia nam lepsze zrozumienie karaimskiej perspektywy oraz kontekstu, w którym owa społeczność postrzegała postać króla Dawida.

1 Krytyczne wydanie tlumaczenia dramatu, wraz z przekładem na język angielski, zostało opublikowane w ubiegłym roku (Smętek 2015). Z kolei oryginał hebrajski został wydany po raz pierwszy w Wiedniu w $1794 \mathrm{r}$. Wydanie dramatu było wielokrotnie wznawiane, najnowsze pochodzi z 1968 r. (pod redakcją Gershona Shakeda).

2 Jego wiersze ukazywały się na łamach $\mathrm{Ha}-\mathrm{Me}$ 'assef, czasopiśmie związanym z grupą literacką Me’assef, do której należał (Waxman 1960: 129).

3 O niniejszym tłumaczeniu wspominają Shapira (2003: 698), Sklare (2011: 456), jak i Jankowski (2012: 61).

$4 \quad$ W artykule poświęconym literaturze krymskokaraimskiej Jankowski wspomina m.in. o Ahab oraz Izebel - dwóch dramatach autorstwa Józefa b. Mordechaja Sułtańskiego omawiających tematykę biblijną (Jankowski 2012: 65). Z kolei Szapszał (1918: 7) wymienia inną sztukę autorstwa Sultańskiego, zatytułowaną Ester, która najprawdopodobniej nigdy nie ukazała się w druku. Na początku dwudziestego wieku wydano komedię A. Lewiego pt. Aхыръ Зэманъ (Ahır Zeman) w Sankt Petersburgu, jak i dwie sztuki Arona Katyka pt. Енияка эски тон (Yeni yaqa eski ton), także w Sankt Petersburgu, oraz Яддec (Yaddes) w Gözleve (Eupatorii) (Zajączkowski 1926: 12-13). Ponadto Jankowski (2012: 52) podaje, że Katyk napisał jeszcze trzy sztuki w języku karaimskim oraz dwie w języku rosyjskim. Można także wspomnieć o dramacie Józefa Eraka pt. Dina (Jankowski 2012: 65), nie cieszył się on jednak uznaniem.

5 Rękopis, który jest w moim posiadaniu, powstał w 1876 lub 1875 roku, czyli kilkadziesiąt lat po pierwotnym tłumaczeniu. Jest to jeden z odpisów tłumaczenia dramatu, które krążyły wśród mniejszości karaimskiej. 
Dramat Melukat $\check{S}^{2} u l^{6}$, w przeciwieństwie do rzeczowego i zwięzłego tekstu Starego Testamentu, w sposób obrazowy i drobiazgowy opisuje stan duszy i umysłu biblijnych postaci - autor stara się przedstawić psychologiczne uzasadnienie ich postępowania. Głównym motywem, wokół którego toczy się akcja, jest narastający konflikt pomiędzy młodym Dawidem a zgorzkniałym Saulem. Ten pierwszy jest ukazany jako chłopiec pełen ideałów, pragnący jak najlepiej służyć swojej rodzinie, a także królowi. Jest młody, silny, utalentowany, przystojny, ma też dobre i łagodne serce. W oczach starego króla wpierw jawi się jako dar od Boga, który ukoi jego zszargane nerwy grą na skrzypcach ${ }^{7}$. Wkrótce jednak pozbawiony łaski bożej Saul zaczyna pałać nienawiścią do chłopca - pozbawionego jakichkolwiek wad bożego wybrańca. W ten sposób rozpoczyna się pełen napięć, wzlotów i upadków dramat, w którym miłość i podziw miesza się z zazdrością i nienawiścią.

\section{Dawid jako bogobojny młodzieniec}

Dawid jest ukazany po raz pierwszy w drugim akcie dramatu. Z Pierwszej Księgi Samuela dowiadujemy się jedynie, że był przystojnym chłopcem i zajmował się wypasem owiec (1 Sm 16:11-12). Natomiast w Meluḱat Šảul już w pierwszej scenie napotykamy na obrazowy opis młodzieńca jako odważnego i pobożnego wojownika, który pokonawszy lwa zagrażającego życiu jego owiec, zaczyna śpiewać pieśń pochwalną do Boga. Poniżej cytuję jej fragment:

David:(...) Severim seni Allah. Yaşhğımdan beri sevdim señi. Daha canmm içimde iken heveslidir yoluñm bilmeye. Nice ğayet büyük olduñ kökte ya Allah. Hacaba maqbul olur mu aşaḩa ayarlğı̃ teşbihatı ${ }^{8}$ ona ki cümle yuqarki eskerler çökeyirler. Bizden ayrnsin gözlere görünmezsin. Sabur èdmek elimden gelmez. Qalbım teşekkür vèrdi saña, içerimde duyğunhq éden yüregim ki bum seniñ qudretiñ var èttiler. (...) Seniñ èttiginiñ ve hikmetiñni cümleye beyan édmeye, benim canma bu hoṣ gelir (Smętek 2015: 127).

6 W rękopisie brak karty tytułowej, dlatego nie podaję krymskokaraimskiego tytułu dzieła. Na podstawie artykułu Szapszała (1918: 7) możemy przypuścić, że brzmiał Şaul Han 'Król Saul'.

7 W przekładzie pojawia się wyraz keman 'skrzypce' (Smętek 2015: 121), jest to zgodne z oryginałem hebrajskim dramatu. Z kolei wg kanonu biblijnego Dawid grał na cytrze (1 Sm 16:23).

8 Fraza aşaḥa ayarlğıñ teşbihatı została błędnie przetłumaczona w rękopisie krymskokaraimskim. Tłumaczenie polskie zostało poprawione na podstawie oryginału hebrajskiego (Ha-Efrati 1821: 10a). 
'Dawid: (...) Kocham Cię, Boże. Kocham Cię od dzieciństwa. Pragnę uczyć się Twych ścieżek tak długo jak żyję. O Boże, jak wielki jesteś na niebiosach! Ciekawe, czy (Pan) docenia wdzięczność skromnego człowieka, skoro klękają przed nim wszyscy wysocy rangą wojskowi. Jesteś inny niż my, oczy nie są w stanie Ciebie dostrzec. (A ja) nie potrafię być cierpliwy. Moje serce, które jest wypełnione uczuciami, jest Ci wdzięczne, bo to Ty je stworzyłeś. (...) Raduje mnie, że mogę przed wszystkimi rozsławiać to, co uczyniłeś i Twoją mądrość.'

Tekst piosenki, która jest wykonywana przy dźwiękach skrzypiec, ukazuje prostolinijną i dziecięco ufną wiarę Dawida. Do tej pory nie zaznał jeszcze w życiu jakiejkolwiek krzywdy, jego dzieciństwo było przepełnione spokojem i miłością rodzicielską. Stąd słowa jego pierwszego monologu utrzymane są w radosnym tonie. Pod koniec wypowiedzi chłopiec zwraca się ku pokonanemu przez siebie lwu, wyrażając żal, że spotkała go przedwczesna śmierć. Podkreśla, że nie czerpie satysfakcji z zadawania cierpienia, nawet jeśli zwierzę na nie zasługiwało. Słowa te antycypują czyny króla Saula, który w kolejnych aktach sztuki nie okaże analogicznego miłosierdzia Dawidowi.

\section{Przyjaźń z Jonatanem}

Jednym z głównych wątków dramatu jest przyjaźń Dawida i Jonatana. Autor poświęca jej przedstawieniu wiele scen, a czytelnik odnosi wrażenie, że relacja tych dwojga jest ważniejsza i silniejsza niż małżeństwo Dawida z królewską córką, Mikal. Od pierwszego spotkania dwoje mężczyzn zaczyna darzyć się głębokim uczuciem. Jonatan jest oczarowany urokiem i skromnością Dawida, który z kolei podziwia serdeczność królewskiego syna wobec zwykłego pasterza. Waxman (1960: 131) argumentuje, że opis ich braterskiej miłości w Meluḱat $̌$ S’ul ma na celu ukazanie idei równouprawnienia wszystkich ludzi, niezależnej od pozycji społecznej. Potwierdza to dialog, który mężczyźni prowadzą w trzecim akcie sztuki:

David: (...) hep bunlardan ziyede quybath olduñ. Eyiligiñniñ büyükligini bana göstürmeye başladiñ. Unuttıñ padişahhlq damariñn, qardaşım dediñ bana. Endi benden vaz geçme. Çözme ol bağı hangisi ilen yüreklerimiz ve canlarımz bağlanmıs oldular.

Yonatan: Her ne qadar canm içimdedir David qardaşıñ olurum. Her ne qadar qulaqlarım eşitirse ayaqlarm gezerse qalbım bilir ki geñe daha dostuñ olurum. Canm barabarn severim seni (Smętek 2015: 157-159).

9 Wszystkie tłumaczenia na język polski zostały przygotowane przez autorkę na potrzeby niniejszego artykułu. 
'Dawid: (...) jesteś mi droższy niż oni wszyscy. Zacząłeś okazywać mi jak wielka jest twoja dobroć. Zapomniałeś o królewskiej krwi, która płynie w twoich żyłach, nazwałeś mnie swoim bratem. Nie opuszczaj mnie (także) teraz. Nie (próbuj) rozwiązywać tej więzi, którą zostały połączone nasze serca i dusze.

Jonatan: Dawidzie, będę twoim bratem tak długo jak żyję. Me serce wie, że będę twoim przyjacielem dopóki me uszy słyszą, a me stopy kroczą. Kocham cię całą moją duszą.'

Tropplowicz wiernie oddaje emocje ukazane w Pierwszej Księdze Samuela, która podaje: „(...) dusza Jonatana przylgnęła całkowicie do duszy Dawida. Pokochał go Jonatan tak jak samego siebie” (1 Sm 18:1). W tekście biblijnym wzmianka o wielkiej miłości królewskiego syna do Dawida pojawia się jeszcze kilkakrotnie, lecz jest za każdym razem zwięzła, bez głębszej analizy uczuć. Sztuka prezentuje swoisty komentarz, uzupełniający psychologiczny wymiar postaci Jonatana, który w akcie czwartym deklaruje, iż Dawid jest mu bliższy i bardziej drogi niż jego własny ojciec. Dramatycznie zapewnia, że jeśli chłopiec zostanie zgładzony, to on także pragnie umrzeć (Smętek 2015: 229) ${ }^{10}$. W kolejnych aktach znajdujemy potwierdzenie, że jego uczucie jest w pełni odwzajemnione. Kiedy Dawid po ucieczce z pałacu ukrywa się przed królewskim gniewem, nie trapi go fakt, że Saul potraktował go jak zdrajcę. Pokłada ufność w Bogu i liczy, że Saul opamięta się, dostrzeże, że postępuje niewłaściwie. Chłopca zasmuca przede wszystkim rozstanie z najbliższym przyjacielem. Paradoksalnie osoba, za którą tęsknota powoduje cierpienie, jest jednocześnie źródłem jego otuchy. Dawid wyraża te uczucia za pomocą poetyckiej metafory: Eger qasavet bulutlar başımiñ üzerine yel esse seniñ muhabbetligini qardaşım fikirime getirirsem bulutlar dağılalar (Smętek 2015: 241) 'Kiedy wiatr przywiewa chmury smutku nad moją głowę, wtedy myślę o twojej miłości, bracie, i chmury rozwiewają się.

\section{Małżeństwo z Mikal}

O ile zażyłe stosunki Dawida i Jonatana są przedstawione w dramacie w najdrobniejszych szczegółach, o tyle związek przyszłego króla z żoną jest potraktowany zdawkowo, jako pośledni wątek nie mający znacznego wpływu na rozwój wydarzeń. Należy zwrócić uwagę, że w sztuce Dawid poświęca Mikal tylko kilka słów. Jest to zgodne z tekstem Pierwszej Księgi Samuela, w którym

10 Natomiast Biblia podaje, że Jonatan był jedynie zmartwiony, ponieważ ojciec nie posłuchał jego rad w kwestii ułaskawienia Dawida (1 Sm 20:33-34). 
możemy odnaleźć jedynie lakoniczną wzmiankę o ich miłości. Jej treść brzmi następująco: „Ale Mikal, córka Saula, pokochała Dawida” (1 Sm 18:20)" ${ }^{11}$ Stary Testament nie zawiera wskazówek odnośnie do emocji Dawida.

Natomiast w dramacie Mikal wielokrotnie wyraża swoje oddanie i uczucie, podziwiając wręcz nadludzkie przymioty męża oraz opisując targającą nią tęsknotę i smutek po ucieczce Dawida z królewskiego pałacu. W piątym akcie Mikal zwraca się w następujących słowach do swojego brata, Jonatana:

Mihal \{behzun\}: (...) Daha ne qadar ömürüm var ise peklerim umud gesmemce. Qädașlarmmiñ quybathsı, sen bilirsin benim qocammiñ qalbiñ. Eger kökdeki malayikler yerde gesseler onlar da utanalar, zira Yişay'nñ oğlunuñ şafafı onlardan ziyede aydınhq verir. Baq qardaşım qızqardașiñm gözleriniñ göz yașlarmm, baq kirpikleriniñ qizarmasın ki suv gibi aqayırlar (Smętek 2015: 261-263).

'Mikal \{smutna\}: (...) Będę czekać do końca mojego życia (na Dawida), dopóki mam nadzieję. Najdroższy z mojego rodzeństwa, ty znasz serce mojego męża. Gdyby anioły, które żyją w niebie, chodziły po ziemi, zawstydziłyby się, ponieważ blask syna Jessego ${ }^{12}$ jaśnieje bardziej od ich (blasku). Bracie, spójrz na łzy w oczach twojej siostry, spójrz jak zaczerwienione są (oczy wokół) jej rzęs, ponieważ (jej łzy) płyną jak potoki ${ }^{13}$.

Mimo że autor Meluǩat $\check{S}^{2} u l$ poświęca wiele miejsca opisom wzajemnych relacji postaci, nie uznał za stosowne napisać wspólny dialog małżonków. Jest to w pełni zrozumiałe, jako że Dawid otrzymał rękę królewskiej córki w nagrodę za swe bohaterskie czyny na rzecz ludu Izraela ${ }^{14}$, a nie z powodu wielkiej miłości. Jak wiemy, w owych czasach śluby możnowładców miały charakter polityczny. W dramacie Mikal jest świadoma roli, którą wypełnia. Tęskniąc za mężem po jego ucieczce, wypowiada znamienne zdanie: Topraq parçası benim gibi çürük act canl qarn 'Podła ${ }^{15}$ cierpiąca kobieta, taka jak ja, jest (tylko) pyłkiem kurzu' ${ }^{16}$ (Smętek 2015: 265).

11 Informacja o uczuciach Mikal pojawia się jeszcze raz w tym samym rozdziale, lecz jej treść jest identyczna: „Mikal, córka Saula, kochała go (Dawida)” (1 Sm 18:28).

12 Tj. Dawida.

13 Dosłownie: 'jak woda'.

14 Była to przyczyna oficjalnie podana do wiadomości. W rzeczywistości zgoda na małżeństwo Dawida była jednym z elementów spisku Saula, mającym na celu zgładzenie chłopca.

15 Dosłownie: 'zgniła'.

16 Dosłownie: 'drobiną ziemi'. 


\section{Konflikt z Saulem}

Tak jak zostało wcześniej wspomniane, oś dramatu stanowi rywalizacja starego króla i jego następcy. Jest to jednak rywalizacja jednostronna - to Saula prześladuje lęk przed utratą tronu i chwały. Pierwszym punktem zwrotnym tej relacji jest pokonanie Goliata przed Dawida. Król Saul odnosi wrażenie, że lud, skandując na ulicach Şaul biñlerini urdu lakin David tümenlerini (Smętek 2015: 189) 'Saul pobił tysiące, lecz Dawid dziesiątki tysięcy', wszelkie zasługi w wojnie z Filistynami przypisuje chłopcu. Ta fraza, śpiewana przez wiwatujące kobiety, została zaczerpnięta bezpośrednio z tekstu biblijnego ${ }^{17}$, jednakże w Pierwszej Księdze Samuela Saul wspomina o niej tylko raz. Zaś w sztuce jest ona wypowiadana siedmiokrotnie, wzmacniając efekt dramatyczny i ukazując, jak jedno zdanie potrafi zburzyć spokój psychiczny danej osoby. Król przeklina śpiewające kobiety, które w jego oczach zdają się z niego kpić. Podkreśla, że wolałby zostać pochłonięty przez piekło niż usłyszeć te słowa. Następnie po raz pierwszy ogarnia go atak szaleństwa i zaczyna snuć prorocze, mroczne wizje. Postanawia zgładzić Dawida. Ten natomiast, dowiedziawszy się o spisku na swoje życie, ucieka w ostatniej chwili z pałacu króla.

Dawid, prezentujący w sztuce skrajnie odmienną postawę od Saula, jest ukazany jako osoba w pełni pogodzona ze swym losem. Nie żywi żalu do króla za prześladowanie, które go spotyka. Jest przekonany, że wszelkie ludzkie czyny, te dobre, a także te niegodziwe, zostały z góry zaplanowane przez Boga. W jednym z monologów podkreśla, że Bir şey olmaz onñ emiri olmaynnca (Smętek 2015: 271) 'Nic się nie wydarza bez jego (bożego) rozkazu'. Stąd też należy przyjmować z pokorą wszystkie wyroki losu. Głęboka wiara chłopca, która pozwala mu mężnie znosić nieszczęścia, nie sprawia jednak, że jest pozbawiony współczucia i nie porusza go cierpienie ludzi, a także wszelkich istot zamieszkujących ziemię. Swą empatię wyraża w rozbudowanym monologu, którego fragment cytuję poniżej:

David: (...) qalbmmiñ duyğunhqlan her şeyden yumșanrlar. Şurada görürsem yeri yaran sabancı cift ögüz haydayaraq onlarn degeneklen dövdügüni ecirim onlar. Baqarsam ayaqlarmnñ altına ki orada bir kiçik qarnca ögüziñ ayaqlarından baslayur. Çeviririm gözlerimi ondan gökge qarşı qaldırırm, vah ki şurada uçan qarağuş bunaynr kiçik quşu. Ona bir qabahat èdmemege ditrerim. Lakin evle emir ètti Yaradan evvelden evle nizam qurdu. Eger dünya bundan eyi olmaq mümkün olsa èdi onu da èderdi (Smętek 2015: 271).

$17 \quad$ Por.: $1 \mathrm{Sm}$ 18:7. 
'Dawid: (...) każde wydarzenie porusza ${ }^{18}$ uczucia w moim sercu. Kiedy widzę oracza, który orze ziemię i pogania parę wołów, uderzając je kijem, to jest mi ich żal. Kiedy patrzę pod ich nogi, (widzę) małą mrówkę, która zostaje zdeptana przez wołu. Odwracam od nich oczy, zwracam je ku niebu, och, a tam leci orzeł, który prześladuje małego ptaka. Lękam się, by go nie skrzywdził. Lecz takie są rozkazy Stwórcy, taki porządek ustalił przed wiekami ${ }^{19}$. Gdyby świat mógłby być lepszy niż jest obecnie, (jestem pewien, że) takim by go uczynił.'

Powyższych refleksji brak w Starym Testamencie, w którym podano jedynie, że Dawid bardzo lękał się o swoje życie (1 Sm 23:15). Otrzymujemy natomiast dokładny opis długotrwałych poszukiwań Saula oraz kolejnych ucieczek Dawida, który szukał schronienia m.in. w jaskini Adullam, w Mispe, Keili i na pustyni Zif. Dowiadujemy się także, że Saul, mimo wytężonych starań i okrutnych metod postępowania ${ }^{20}$, nie był w stanie pochwycić chłopca.

Dokładniejszy opis uczuć Dawida pojawia się dopiero w dwudziestym czwartym rozdziale Pierwszej Księgi Samuela. Zostaje on przedstawiony w przełomowym momencie w relacji starego króla i młodego pretendenta do tronu. Dawid ukrywał się w głębi jaskini Engaddi, a Saul odpoczywał u jej wejścia, nie będąc świadomym tego, kto czai się w jej wnętrzu. Scena ta mogła zakończyć się ostatecznym tryumfem chłopca, który otrzymał szansę, by zabić Saula i uwolnić się od prześladowań. Jednak Dawid najpierw odcina skraj królewskiego płaszcza, a następnie rezygnuje z podniesienia ręki na władcę, by nie popaść w bożą niełaskę. Następnie konfrontuje się z Saulem, tłumacząc, że miał okazję, by go zabić. Jednak nie zrobił tego, ponieważ jego intencje są szczere, nie ma w nim nienawiści i chęci do zdrady. Wciąż chce wiernie służyć prawowitemu władcy. Słowa Dawida są pełne goryczy i żalu. Z wyrzutem żąda od Saula wyjaśnień, dlaczego ten pragnie jego śmierci. W tym momencie króla opuszcza na chwilę szaleństwo, dostrzega niewinność chłopca i przysięga, że nie będzie go już prześladował ${ }^{21}$.

Tropplowicz wykorzystał powyższe wydarzenie, aby wykreować poruszającą scenę końcową w szóstym akcie sztuki. W dramacie pojednanie następuje nie

18 Dosłownie: 'zmiękcza'.

19 Dosłownie: 'wcześniej'.

20 Wybił m.in. ród Achituba, oskarżając go o sprzyjanie Dawidowi (1 Sm 22:6-23).

${ }^{21}$ Jednak, jak dowiadujemy się z kolejnych rozdziałów Pierwszej Księgi Samuela, król niedługo potem ponownie zaczyna ścigać Dawida, ulegając kolejnym napadom szaleństwa. 
w jaskini, lecz później, na chwilę przed śmiercią starego króla. O ile według Pisma Świętego zgoda Saula i Dawida trwała jedynie chwilę, o tyle w Meluḳat $\check{S} \mathfrak{a}^{\jmath} u l$ autor przestawia bardziej optymistyczne zakończenie relacji tych dwojga. W finałowej scenie Saul umiera na wzgórzu Gilboa, a Dawid klęka koło niego. Władca w ostatnich chwilach życia odzyskuje zdrowy rozsądek, błaga Dawida o wybaczenie i przyznaje się do popełnionych grzechów. Rekoncyliacja umierającego króla z jego następcą ma na celu ukazać, że każdy człowiek ma prawo błądzić, lecz wszystkie przewinienia mogą zostać zapomniane, jeśli tylko okaże się skruchę. Wydźwięk tej sceny jest zupełnie inny od tonu wydarzeń przekazanych w Starym Testamencie, w którym Saul ginie w dramatycznych okolicznościach. Król wie, że jego synowie Jonatan, Abinadab i Malkiszua zostali zgładzeni przez Filistynów i umiera ze świadomością całkowitej klęski. Po śmierci wrogowie odcinają mu głowę i zdzierają z niego zbroję (1 Sm 31:1-9). Autor Melukat $\breve{S} a^{2} u l$ był wobec Saula zdecydowanie bardziej litościwy.

\section{Podsumowanie}

Postać młodego Dawida została przedstawiona w maskilskim dramacie w sposób jednostronny i wyidealizowany. Chłopiec posiada łagodne usposobienie, jest nadludzko wyrozumiały wobec swoich wrogów, a jego lojalność pozostaje niewzruszona mimo niegodziwości popełnianych przez ówczesnego władcę Izraela. Gershon Shaked zarzucił autorowi Melukat $\breve{S} a^{2} u l$ zbyt enigmatyczne opisywanie głównych postaci. W jego ocenie przypominają one bardziej chodzące ideały, niż ludzi z krwi i kości (Shaked 1968: 25-26) 22. Nie sposób odmówić mu racji w kwestii przedstawienia charakteru Dawida. Jest to jednak świadoma hiperbolizacja cnót, która ma na celu tym bardziej wyraziste skontrastowanie młodzieńczej niewinności z nikczemnością króla Saula, który targany negatywnymi emocjami pogrąża się w szaleństwo. Stary król jest rozdarty między tęsknotą za utraconą potęgą a rodzącym się serdecznym uczuciem do utalentowanego chłopca $^{23}$.Zabieg hiperbolizacji należy uznać za udany, jednak w rezultacie opis postaci Dawida stał się jednowymiarowy. Służy głównie za lustro, w którym przegląda się zgorzkniały król Saul.

\footnotetext{
22 Przedmowę autorstwa Shakeda cytuję za Fishmanem (1995: 157) ze względu na niewystarczającą znajomość języka hebrajskiego.

23 Ambiwalentne uczucia Saula w Meluḱat Ša ul zostały szerzej omówione w Smętek (2012: 524-526).
} 


\section{Symbole}

( ) = wyrazy dodane przez autorkę

$(\ldots)=$ pominięte frazy

\{\}$=$ tekst umieszczony $\mathrm{w}$ didaskaliach

\section{Bibliografia}

Ha-Efrati, Józef Tropplowicz. 1821. Melukat Ša’ul ha-Melek ha-Rišon al Yešurun, Kraków. Jankowski, Henryk. 2012. Literatura krymskokaraimska, „Przegląd Orientalistyczny”, nr 1-2, s. 50-68.

Fishman, David E. 1995. Russia's First Modern Jews: The Jews of Shklov, New York - London.

Pismo Święte Starego i Nowego Testamentu, Biblia Tysiaclecia, Wyd. 3 popr. 1990. Poznań - Warszawa.

Shaked, Gershon. 1968. Przedmowa, [w:] Melukhat Sha'ul, Jerusalem.

Shapira, Dan. 2003. The Turkic Languages and Literatures of the East European Karaites, [w:] red. Meira Polliack. Karaite Judaism. A Guide to its History and Literary Sources, Leiden - Boston, s. 657-707.

Sklare, David E. 2011. Lutski family, [w:] The Oxford Dictionary of the Jewish Religion. Second Edition, red. Adele Berlin, New York - Oxford, s. 456.

Skolnik, Fred (red.). 2007. Joseph Ha-Efrati (Tropplowitz), [w:] Encyclopaedia Judaica. $2^{\text {nd }} \mathrm{ed}$. V. 8, Detroit, s. 195.

Smętek, Dorota. 2012. Crimean Karaite Translation of a Hebrew Drama "Melukhat Sha'ul" as an Example of Rabbinic Literature's Influence on Literary Activity of the Crimean Karaites, ,Jewish History Quarterly", nr 244, 4, s. 520-529.

Smętek, Dorota. 2015. Crimean Karaim Version of Melukhat Sha'ul. Critical Edition and Linguistic Analysis [= Turkic Studies 5], Poznań.

Szapszał, Seraja. 1918. Kratkij očerk tjurksko-karaimskoj literatury, „Izvěstija Karaimskago Duxovnago Pravlenìja”, nr 1, s. 6-10; nr 2, s. 13-17.

Waxman, Meyer. 1960. A History of Jewish Literature. V.3. From the Middle of the Eighteenth Century to 1880, New York - London.

Zajączkowski, Ananiasz. 1926. Literatura karaimska (Szkic bibliograficzny), „Myśl Karaimska", nr 1, z. 3, s. 7-17. 